\title{
Identification, Mefenoxam Sensitivity, and Compatibility Type of Phytophthora spp. Attacking Floriculture Crops in North Carolina
}

\author{
J. Hwang and D. M. Benson, Department of Plant Pathology, North Carolina State University, Raleigh 27695
}

\begin{abstract}
Hwang, J., and Benson, D. M. 2005. Identification, mefenoxam sensitivity, and compatibility type of Phytophthora spp. attacking floriculture crops in North Carolina. Plant Dis. 89:185-190.

Phytophthora isolates were collected from floriculture crops grown in commercial greenhouses in North Carolina for species identification, compatibility type determination, and mefenoxam sensitivity tests. Isolation from 41 symptomatic plant species at 29 production locations resulted in 483 isolates from eight crops at seven locations. Phytophthora cryptogea (184 isolates) was recovered from dusty miller and gerbera daisy. All isolates of $P$. cryptogea were insensitive or intermediate in sensitivity to mefenoxam at $1 \mu \mathrm{g}$ a.i./ml and were $\mathrm{A} 1$ compatibility type. $P$. nicotianae (273 isolates) was isolated from African violet, lavender, pansy, petunia, and vinca. Of these isolates, $21 \%$ were insensitive to mefenoxam at either 1 or $100 \mu \mathrm{g}$ a.i./ml. Isolates of $P$. nicotianae from five locations were A2 compatibility type, whereas isolates on pansy at one location were A1 compatibility type. English ivy grown at two locations was infected with $P$. palmivora. All 26 isolates of $P$. palmivora were sensitive to mefenoxam and were A1 compatibility type. Mating type and mefenoxam sensitivity were uniform among isolates of $P$. nicotianae and $P$. palmivora from a given crop at a given location, suggesting that epidemics within a location may have originated from a single source of inoculum.
\end{abstract}

Additional keywords: $\mathrm{EC}_{50}$, phenotypic diversity, survey
The wholesale value of floriculture crops in the United States was estimated at $\$ 4.88$ billion in 2002 (29). Floriculture crops are relatively high-value crops with intensive labor needs and little tolerance for plant damage; therefore, economic loss can be severe if plant diseases develop. Several Phytophthora spp. are known to cause root rot, crown rot, and foliar blight on a variety of floriculture crops grown in greenhouses $(5,7)$. Managing Phytophthora diseases on floriculture crops can be difficult, considering favorable environmental conditions for the pathogen inside greenhouses and the biology of the pathogen. Disease development may be favored by warm and humid conditions, with pathogen inoculum and ample host plants in year-round production. Dispersal of motile zoospores of Phytophthora spp. in recycling irrigation water may further compound the problem $(27,30)$. In addition, regional, national, and international move-

Corresponding author: D. M. Benson

E-mail: mike_benson@ncsu.edu

This research was supported in part by the American Floral Endowment, Glen Carbon, IL; the USDA-ARS Floriculture and Nursery Crops Initiative, Specific Cooperative Agreement no. 58-66450-233; and the North Carolina ARS, North Carolina State University, Raleigh.

Accepted for publication 30 September 2004.

DOI: 10.1094/PD-89-0185

(C) 2005 The American Phytopathological Society ment of large volumes of plant material is common in the floriculture industry. It is highly possible that propagules of the pathogen can be dispersed long distances in a short period of time along with infected plant materials, and cause an outbreak where they have been introduced.

Fungicide application is a major component in the management of Phytophthora diseases on floriculture crops (5). Metalaxyl and a similar isomer, mefenoxam, are systemic phenylamide fungicides selective for Oomycete pathogens (23). Growers continue to rely on these compounds due to the effectiveness of the products, but fungicide resistance has now developed $(8,15)$.

Monitoring the proportion of a pathogen population resistant to a fungicide can be essential to develop management strategies that can delay or prevent development of resistance to fungicides and fungicide failure $(25,26)$. Monitoring a pathogen population also can detect the movement of indigenous pathogen propagules as well as the introduction of exotic pathogens. In a previous study (14), the movement of isolates of Phytophthora drechsleri and $P$. nicotianae within a production site and among production facilities was investigated by comparison of mefenoxam sensitivity, compatibility type, and amplified profile. Because the pathogen population was clonal, asexual reproduction was responsible for epidemics within a facility. Spread of the pathogen among facilities occurred via movement of infected plant materials (14).

An inclusive survey for a pathogen over an extended period of time can provide valuable information on the occurrence and distribution of the pathogen. Characterization of a pathogen population allows monitoring of fungicide resistance development as well as dispersal of the pathogen, information that is critical for successful disease control. However, little is known concerning the current status of Phytophthora diseases on floriculture crops in North Carolina because an extensive, statewide survey has not been done. The objectives of this study were to identify Phytophthora spp. attacking floriculture crops grown in North Carolina and to characterize these isolates based on their mefenoxam sensitivity and compatibility type.

\section{MATERIALS AND METHODS}

Isolate collection. From 2001 to 2002, a total of 41 plant species with symptoms of fragment length polymorphism (AFLP)

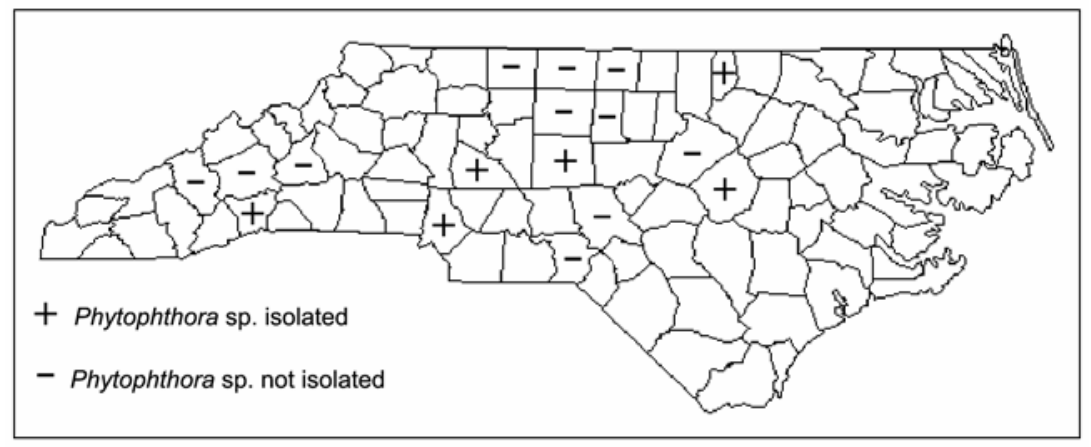

Fig. 1. Production locations of greenhouses in North Carolina surveyed for Phytophthora spp. in 2001 and 2002. Phytophthora spp. were isolated (+) from greenhouse locations in 6 of 17 counties surveyed. No Phytophthora sp. was recovered from greenhouse locations in the other 11 counties surveyed (-). 
leaf blight, crown rot, or root rot were sampled in greenhouses at 29 production locations from 17 counties in North Carolina (Fig. 1). Production facilities were selected randomly and were diverse in size and production scale. Some of these sites were family-operated greenhouses with less than $2,000 \mathrm{~m}^{2}$ of production area, whereas others were large-scale operations with over 100 employees on site. Up to 120 symptomatic plant samples were collected throughout the greenhouse ranges for a given plant species at each location. Plant samples were kept in an insulated chest with ice to minimize tissue deterioraples from the survey site to the laboratory, where the samples were stored at $4{ }^{\circ} \mathrm{C}$ until processed. Plant samples were washed under running tap water and leaf, stem, or root tissues with margins of developing lesions were selected for isolation. Phytophthora spp. were isolated from plant samples by plating infected tissues on cornmeal agar (CMA) amended with pimaricin, ampicillin, rifampicin, and pentachloronitrobenzene (PARP) with or without hymexazol (12). The plates were kept at ambient temperature $\left(23\right.$ to $\left.25^{\circ} \mathrm{C}\right)$ in the dark for up to 14 days. Mycelial growth on the media was examined under a microscope for the presence of hyphae of Phytophthora spp. Developing Phytophthora colonies were transferred to new PARPCMA media. After $48 \mathrm{~h}$, a sequential transfer of actively growing hyphal tips to a fresh CMA plate was done to establish an axenic culture. For long-term storage, a 5mm-diameter agar plug from the edge of a colony was placed into a $25-\mathrm{ml}$ tube with 9 $\mathrm{ml}$ of CMA. After incubation at ambient temperature in the dark for 7 days, the isolates were stored at $18^{\circ} \mathrm{C}$. An isolate was defined as a culture of a Phytophthora tion during the transportation of the sam-

sp. recovered from an individual plant grown at a given location on a given survey date. A group was defined as several isolates of Phytophthora spp. collected from the same plant species grown at a given production location on a given date of survey.

Species identification. Isolates were identified to species based on morphological and physiological characteristics $(7,24)$. Morphology of sporangia was examined after incubation of the cultures on either CMA or V8 broth $(200 \mathrm{ml}$ of V8 clarified juice plus $800 \mathrm{ml}$ of sterile deionized water) under continuous fluorescent light for 3 to 7 days. Clarified V8 juice was prepared by filtering V8 juice through a 3cm-thick layer of Celite 545 (Fisher Scientific, Fair Lawn, NJ) after adding $2 \mathrm{~g}$ of $\mathrm{CaCO}_{3}$. Twice-autoclaved vinca (Catharanthus roseus) leaves colonized with a Phytophthora isolate were placed in a petri plate, then flooded with sterile tap water. After the formation of sporangia, flooded vinca leaves were shaken on a rotary shaker at $200 \mathrm{rpm}$ for $1 \mathrm{~min}$ for determination of sporangial caducity and length of pedicels.

Species identifications were confirmed with a polymerase chain reaction (PCR) technique with internal transcribed spacer (ITS) primers ITS 5 (5' GGAAGTAAAAGTAACAAGG) and ITS 4 (5' TCCTCCGCTTATTGATATGC) as described by Ristaino et al (22). Three to four isolates representing each group were grown in pea broth for 7 days at ambient temperature. Pea broth was prepared by autoclaving $120 \mathrm{~g}$ of frozen peas in $500 \mathrm{ml}$ of deionized water. After filtration through several layers of cheesecloth, the filtrate was brought to 1 liter with deionized water and autoclaved for $25 \mathrm{~min}$. Mycelia of isolates were filtered and collected into

Table 1. Species, host plant, and location where isolates were recovered, and designation of isolates of Phytophthora spp. used as a reference in polymerase chain reaction confirmation of species identification and as testers in compatibility type tests

\begin{tabular}{|c|c|c|}
\hline Species, host, and location & Isolate designation & Compatibility type \\
\hline \multicolumn{3}{|l|}{ Phytophthora capsici } \\
\hline Cucurbits, Michigan & OP97b & A1 \\
\hline Cucurbits, Michigan & SP98 & $\mathrm{A} 2$ \\
\hline \multicolumn{3}{|l|}{ P. cryptogea } \\
\hline Aster, California & $\mathrm{ATCC} 15402^{\mathrm{c}}$ & A1 \\
\hline Dusty miller, North Carolina & FDM & A1 \\
\hline Godetia sp., South Africa & $\mathrm{ATCC} 15403^{\mathrm{c}}$ & A2 \\
\hline \multicolumn{3}{|l|}{$P$. nicotianae } \\
\hline African violet, North Carolina & VAV & $\mathrm{A} 2$ \\
\hline Pansy, Maryland & $223^{d}$ & $\mathrm{~A} 2$ \\
\hline Pansy, North Carolina & FBPS & A1 \\
\hline Verbena, New York & $221^{\mathrm{d}}$ & $\mathrm{A} 2$ \\
\hline \multicolumn{3}{|l|}{$P$. palmivora } \\
\hline Citrus, Florida & P8 & A1 \\
\hline Citrus, Florida & $\mathrm{P} 29^{\mathrm{e}}$ & A1 \\
\hline
\end{tabular}

a All Phytophthora isolates from the survey initially were paired with $P$. capsici OP97 and SP98. P. cryptogea ATCC15402 and ATCC15403, P. nicotianae 221 and 223, and P. palmivora P8 and P29 were used as reference species.

b Isolates provided by K. H. Lamour.

c Isolates provided by $\mathrm{S}$. H. Kim.

${ }^{\mathrm{d}}$ Isolates provided by M. L. Daughtrey.

e Isolates provided by J. B. Ristaino (22). 1.5-ml microtubes. DNA was extracted by a hexadecyltrimethylammonium bromide (CTAB) procedure (11). The PCR with the ITS 5 and ITS 4 primers was conducted in $50-\mu$ reaction volumes. Each reaction tube contained $1 \mu \mathrm{l}$ of a $1-\mathrm{ng} / \mu \mathrm{l}$ DNA template, $36.6 \mu \mathrm{l}$ of sterile distilled water, $5 \mu \mathrm{l}$ of 10× PCR buffer (Boehringer Mannheim, Indianapolis, IN), $2 \mu \mathrm{l}$ of $2 \mathrm{mM}$ deoxynucleoside triphosphates (Invitrogen, Carlsbad, CA), $1 \mu \mathrm{l}$ of $10 \mathrm{mM} \mathrm{MgCl}{ }_{2}$ (SigmaAldrich, St. Louis), $2 \mu \mathrm{l}$ of each primer, and $0.4 \mu \mathrm{l}$ of $\mathrm{Taq}(5 \mathrm{U} / \mu \mathrm{l}$, Boehringer Mannheim). The PCR cycle consisted of an initial denaturation at $96^{\circ} \mathrm{C}$ for $2 \mathrm{~min}$ followed by 35 cycles of $96^{\circ} \mathrm{C}$ for $1 \mathrm{~min}$, $55^{\circ} \mathrm{C}$ for $1 \mathrm{~min}$, and $72^{\circ} \mathrm{C}$ for $2 \mathrm{~min}$, and a final extension at $72^{\circ} \mathrm{C}$ for $10 \mathrm{~min}$. Amplified fragments were digested with a series of restriction enzymes including $A l u \mathrm{I}$, HaeIII, MspI, and RsaI. Each digestion tube consisted of $15 \mu \mathrm{l}$ of amplified PCR product and $2 \mu \mathrm{l}$ of enzyme mixture $(1 \mu \mathrm{l}$ of REact buffer [Gibco BRL, Gaithersburg, $\mathrm{MD}], 1 \mu \mathrm{l}$ of restriction enzyme, and $8 \mu \mathrm{l}$ of sterile distilled water). Amplified PCR product was digested at $37^{\circ} \mathrm{C}$ for $3 \mathrm{~h}$ and the reaction was stopped by incubating the product at $65^{\circ} \mathrm{C}$ for $10 \mathrm{~min}$. Digested DNA was resolved and visualized on a $1.5 \%$ agarose gel containing ethidium bromide $(0.5 \mu \mathrm{g} / \mathrm{ml})$ in Tris-borate-EDTA buffer at $55 \mathrm{~mA}$ for $2 \mathrm{~h}$. Fragment sizes in base pairs were calculated with the shareware software SEQAID II (20). Reference isolates for corresponding species were obtained from cooperators (Table 1).

Compatibility type determination. Fresh cultures of each isolate were obtained by transferring agar plugs from stock cultures onto CMA plates. A 6-mmdiameter agar plug from the margin of a growing colony was transferred to either V8-juice agar $(200 \mathrm{ml}$ of clarified V8 juice, $800 \mathrm{ml}$ of deionized water, and $17 \mathrm{~g}$ of agar per liter) or amended V8-juice agar (100 $\mathrm{ml}$ of $\mathrm{V} 8$ juice, $2.5 \mathrm{~g}$ of calcium carbonate, $30 \mathrm{mg}$ of $\beta$-sitosterol, $20 \mathrm{mg}$ of tryptophan, $100 \mathrm{mg}$ of $\mathrm{CaCl}_{2} \cdot \mathrm{H}_{2} \mathrm{O}, 1 \mathrm{mg}$ of thiamine, and $15 \mathrm{~g}$ of agar per liter) as described by Chee et al. (3). Each isolate initially was paired with a known compatibility type isolate of $P$. capsici by placing agar plugs of tester isolates $2 \mathrm{~cm}$ apart from each unknown isolate. Tester isolates of $P$. cryptogea and $P$. nicotianae were used for the isolates which failed to form oospores in pairing with $P$. capsici. The tester isolates were obtained from cooperators and our own collection (Table 1). After incubating the plates at ambient temperature in the dark for 3 to 14 days, the compatibility type of each isolate was determined microscopically based on the presence or absence of oospores.

Mefenoxam sensitivity and $\mathbf{5 0 \%}$ growth inhibition assay. All isolates were screened for fungicide sensitivity based on hyphal growth on CMA amended with mefenoxam. An agar plug from each stock 
culture was transferred to CMA, then incubated at ambient temperature for 3 days to obtain a fresh culture. A 6-mm-diameter agar disk was taken from the margin of each resulting culture and placed at the center of each of three replicate CMA plates containing mefenoxam (Subdue MAXX; Syngenta, Greensboro, NC) at either 0,1 , or $100 \mu \mathrm{g}$ a.i./ml. The plates were incubated at ambient temperature for 4 to 10 days. The diameter of hyphal growth in all plates was measured when colonies in the absence of mefenoxam had reached the edge of the plate. Inhibition by mefenoxam was determined as the percentage of growth in diameter at a given mefenoxam concentration compared with the growth on the nonamended plate. At a given concentration, isolates were defined as (i) sensitive if hyphal growth was none, (ii) intermediate if hyphal growth was less than $50 \%$ compared with the growth on the nonamended plate, or (iii) insensitive if hyphal growth was greater than $50 \%$ of growth of that on the nonamended plate.

Isolates that grew at $1 \mu \mathrm{g}$ a.i. mefenoxam $/ \mathrm{ml}$ were further studied to determine the effective concentration of fungicide giving $50 \%$ growth inhibition $\left(\mathrm{EC}_{50}\right)$. Based on the results from the mefenoxam sensitivity test, three or four mefenoxam concentrations were selected for each group of isolates for appropriate regression analysis. A subset of three isolates within a group was transferred to three replicate plates of CMA amended with mefenoxam at either $0.1,0.2,0.5,10,20,50,200,500$, or $1,000 \mu \mathrm{g}$ a.i./ml. The growth of each isolate relative to the growth on the nonamended plate was determined. The mean across isolates within a subset was subjected to a regression analysis with percent growth expressed on a probability scale and fungicide concentration on a logarithmic scale. The resulting slope value was used to interpolate $\mathrm{EC}_{50}(2)$. Both the mefenoxam sensitivity test and $\mathrm{EC}_{50}$ assay

Table 2. Plant species, number of plants sampled and locations surveyed, and number of Phytophthora isolates recovered from a survey of floriculture crops in North Carolina in 2001 and 2002

\begin{tabular}{|c|c|c|c|}
\hline \multirow[b]{2}{*}{ Plants } & \multicolumn{3}{|c|}{ Number of } \\
\hline & Samples & Locations $^{\mathbf{a}}$ & Isolates \\
\hline African violet, Saintpaulia ionantha & 150 & 1 & 96 \\
\hline Artemisia, Artemisia spp. & 21 & 1 & 0 \\
\hline Begonia, Begonia spp. & 134 & 3 & 0 \\
\hline Campanula, Campanula spp. & 46 & 1 & 0 \\
\hline Carnation, Dianthus caryophyllus & 19 & 2 & 0 \\
\hline Chrysanthemum, Chrysanthemum spp. & 5 & 1 & 0 \\
\hline Cladium, Cladium spp. & 2 & 1 & 0 \\
\hline Cyclamen, Cyclamen persicum & 5 & 2 & 0 \\
\hline Dahlia, Dahlia pinnata & 34 & 1 & 0 \\
\hline Dusty Miller, Cineraria maritima & 161 & 3 & 101 \\
\hline English ivy, Hedera helix & 178 & 5 & 26 \\
\hline Fuchsia, Fuchsia spp. & 46 & 1 & 0 \\
\hline Garden sage, Salvia officinalis & 20 & 1 & 0 \\
\hline Geranium, Pelargonium $\times$ hortorum & 21 & 3 & 0 \\
\hline Gerbera daisy, Gerbera jamesonii & 339 & 9 & 83 \\
\hline Gloxinia, Gloxinia perennis & 88 & 2 & 0 \\
\hline Impatiens, Impatiens spp. & 134 & 5 & 0 \\
\hline Lamb's ears, Stachys byzantina & 18 & 1 & 0 \\
\hline Lantana, Lantana spp. & 76 & 1 & 0 \\
\hline Lavender, Lavandula angustifolia & 65 & 2 & 60 \\
\hline Lisianthus, Eustoma grandiflorum & 30 & 1 & 0 \\
\hline Marigold, Calendula officinalis & 37 & 1 & 0 \\
\hline Miniature rose, $R o s a$ spp. & 25 & 1 & 0 \\
\hline New guinea impatiens, Impatiens $\times$ hybrida & 12 & 1 & 0 \\
\hline Oregano, Origanum spp. & 86 & 2 & 0 \\
\hline Pansy, Viola $\times$ wittrockiana & 253 & 4 & 8 \\
\hline Pentas, Pentas spp. & 150 & 4 & 0 \\
\hline Petunia, Petunia $\times$ hybrida & 233 & 4 & 40 \\
\hline Plectranthus, Plectranthus spp. & 26 & 1 & 0 \\
\hline Poinsettia, Euphorbia pulcherrima & 93 & 3 & 0 \\
\hline Portulaca, Portulaca grandiflora & 87 & 1 & 0 \\
\hline Pothos, Pothos spp. & 24 & 1 & 0 \\
\hline Rhodochiton, Rhodochiton spp. & 76 & 1 & 0 \\
\hline Rosemary, Rosmarinus officinalis & 40 & 1 & 0 \\
\hline Salvia, Salvia spp. & 120 & 2 & 0 \\
\hline Scotch moss, Sagina sublata & 18 & 1 & 0 \\
\hline Snapdragon, Antirrhinum majus & 128 & 3 & 0 \\
\hline Syngonium, Syngonium spp. & 25 & 1 & 0 \\
\hline Verbena, Verbena $\times$ hybrida & 83 & 3 & 0 \\
\hline Vinca, Catharanthus roseus & 603 & 11 & 69 \\
\hline Viola, Viola cornuta & 120 & 1 & 0 \\
\hline
\end{tabular}

${ }^{a}$ In all, 29 production locations in 17 North Carolina counties were surveyed during 2001 and 2002. For some plants, more than one production location was surveyed. For some locations, the survey was repeated over 2 years. experiments were repeated twice with a completely randomized design. Data were analyzed with mefenoxam concentration as a fixed effect in one-way analysis of variance. The data were pooled across experiments based on homogeneity of variances.

\section{RESULTS}

Phytophthora isolation and species identification. A total of 483 Phytophthora isolates were recovered from 3,831 symptomatic plants (41 species) sampled from 29 production locations (Table 2). Among 41 plant species sampled, Phytophthora spp. were isolated from African violet, dusty miller, English ivy, gerbera daisy, lavender, pansy, petunia, and vinca at one or more of seven locations in six counties in North Carolina (Fig. 1).

These isolates were identified as P. cryptogea, $P$. nicotianae, and $P$. palmivora based on morphological and physiological characteristics and PCR (Fig. 2). Isolates of $P$. cryptogea produced nonpapillate, nondeciduous sporangia with internal proliferation on V8 broth. Amphigynous antheridia were produced in the presence of the opposite compatibility type on amended V8-juice agar. Oospores were typically $25 \mu \mathrm{m}$ in diameter with a range of 20 to $29 \mu \mathrm{m}$. Isolates of $P$. nicotianae produced abundant papillate sporangia and chlamydospores on CMA. Sporangia were not caducous. Oospores with amphigynous antheridia were formed in paired cultures on V8-juice agar and ranged in diameter from 22 to $29 \mu \mathrm{m}$. Sporangia of $P$. palmivora were prominently papillate on V8juice agar. Deciduous sporangia had a rounded base and short pedicels when they were detached from sporangiophores. On amended V8-juice agar, oospores were

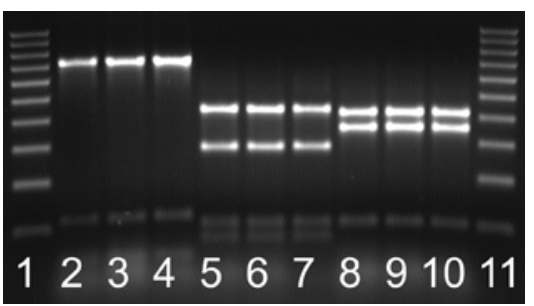

Fig. 2. Restriction analysis of DNA of Phytophthora cryptogea ATCC 15402 (lane 2), $P$. cryptogea ATCC 15403 (lane 3), P. cryptogea isolated from gerbera daisy (lane 4), P. nicotianae 221 (lane 5), P. nicotianae 223 (lane 6), P. nicotianae isolated from petunia (lane 7), $P$. palmivora P8 (lane 8), P. palmivora $\mathrm{P} 29$ (lane 9), and P. palmivora isolated from English ivy (lane 10) amplified with internal transcribed spacer (ITS) primers ITS 5 and ITS 4. Lanes 4, 7 , and 10 are representative isolates of each Phytophthora sp. collected from floriculture crops grown in North Carolina in 2001 and 2002. Amplified DNA of P. cryptogea was digested with HaeIII. DNA of P. nicotianae and $P$. palmivora was digested with $R s a \mathrm{I}$ after amplification. Lanes 1 and 11 contain a 100-bp DNA ladder. 
formed with amphigynous antheridia in paired cultures and typically were $23 \mu \mathrm{m}$ in diameter.

Digestion of amplified DNA of representative isolates of each species identified by restriction enzymes resulted in the same fragment pattern and base pair size previously reported for these species by Ristaino et al (22). In comparison with corresponding reference species (Table 1), isolates of $P$. nicotianae and $P$. palmivora collected in this study showed the same restriction fragment pattern when DNA amplified with ITS 5 and ITS 4 was digested with RsaI. After digestion of amplified DNA of $P$. cryptogea isolates with HaeIII, the restriction pattern of the isolates was consistent with the pattern of reference species (Fig. 2).

Among all the isolates, 38\% (184 isolates) were $P$. cryptogea isolated from dusty miller and gerbera daisy at two locations and $57 \%$ (273 isolates) were P. nicotianae isolated from African violet, lavender, pansy, petunia, and vinca at five locations. A total of 26 isolates $(5 \%)$ of $P$. palmivora were recovered from English ivy at two locations. Even though they were isolated from different plants, $P$. cryptogea and $P$. nicotianae coexisted at one location (Table 3).

Compatibility type of isolates. Regardless of host, all isolates of $P$. cryptogea were identified as compatibility type A1 when the isolates were paired with a tester isolate of a known A2 compatibility type (ATCC 15403). Isolates of $P$. nicotianae were cultured with tester isolates of A1 compatibility type (OP97 and FBPS) and A2 compatibility type (SP98). Seven groups (groups 5, 6, 7, 9, 10, 11, and 12) of isolates collected from African violet, lavender, petunia, and vinca at four locations were A2 compatibility type, while only one group (group 8) of isolates recovered from pansy at one location was A1 compatibility type (Table 3 ). All isolates of P. palmivora collected from English ivy at two locations were A1 compatibility type when they were tested with an A2 compatibility type isolate (VAV).

Mefenoxam sensitivity screening. Of the 483 Phytophthora isolates tested, 248 isolates $(51 \%)$ were sensitive to mefenoxam at either 1 or $100 \mu \mathrm{g}$ a.i./ml (Table 3). All isolates of $P$. cryptogea were either intermediate in sensitivity $(3 \%)$ or insensitive to mefenoxam (97\%) at $1 \mu \mathrm{g}$ a.i./ml. Only five isolates (3\%) of P. cryptogea were sensitive to mefenoxam at 100 $\mu \mathrm{g}$ a.i. $/ \mathrm{ml}$. In all, 57 isolates of $P$. cryptogea $(31 \%)$ were intermediate whereas 122 isolates $(66 \%)$ showed insensitivity to mefenoxam at $100 \mu \mathrm{g}$ a.i./ml. For P. nicotianae isolates, $79 \%$ of the isolates (217 isolates) were sensitive to mefenoxam at either 1 or $100 \mu \mathrm{g}$ a.i./ml and the rest (56 isolates) were insensitive at 1 and $100 \mu \mathrm{g}$ a.i./ml. All isolates of $P$. palmivora were sensitive to mefenoxam at either 1 or $100 \mu \mathrm{g}$ a.i./ml (Table 3). The isolates that showed hyphal growth at $1 \mu \mathrm{g}$ a.i./ml were evaluated over a range of mefenoxam concentrations for $\mathrm{EC}_{50}$. A wide range of the $\mathrm{EC}_{50}$ values (0.1 to $549.5 \mu \mathrm{g}$ a.i. $/ \mathrm{ml}$ ) was obtained for $P$. cryptogea isolates, depending on the production location and host plant. One group of $P$. nicotianae isolates (group 9) had an $\mathrm{EC}_{50}$ value of $269.2 \mu \mathrm{g}$ a.i./ml and the other group (group 10) had a value of $346.7 \mu \mathrm{g}$ a.i./ml (Table 3; Fig. 3).

Phenotypic diversity. Within a given group, 12 of 14 groups of Phytophthora isolates were phenotypically homogeneous based on sensitivity to mefenoxam and compatibility type (Table 3 ). Among these 12 groups, all isolates within a group showed the same level of sensitivity to mefenoxam at a given concentration. All isolates within a group consisted of the same compatibility type. Isolates in group 2 of $P$. cryptogea from dusty miller were of the same compatibility type but heterogeneous for mefenoxam sensitivity. Among 49 isolates within the group, five isolates (group 2-a) had an $\mathrm{EC}_{50}$ value of $0.1 \mu \mathrm{g}$ a.i./ml and were identified as intermediate and sensitive at 1 and $100 \mu \mathrm{g}$ a.i. $/ \mathrm{ml}$, respectively. Another 44 isolates (group 2-b) were insensitive and intermediate at 1 and $100 \mu \mathrm{g}$ a.i./ml, respectively, and their $\mathrm{EC}_{50}$ value was $27.5 \mu \mathrm{g}$ a.i./ml. Isolates in group 3 of $P$. cryptogea from gerbera daisy also showed differences in mefenoxam sensitivity. Among 30 isolates within the group, the $\mathrm{EC}_{50}$ value for 13 isolates in group 3-a was $5.4 \mu \mathrm{g}$ a.i./ml and the value for 17 isolates in group 3-b was $549.5 \mu \mathrm{g}$ a.i./ml (Table 3; Fig. 3).

Over 2 years, isolates of $P$. nicotianae were collected from African violet at the same location. Both groups collected in 2001 and 2002 (groups 5 and 6) showed the same level of sensitivity to mefenoxam at 1 and $100 \mu \mathrm{g}$ a.i./ml and were A2 compatibility type (Table 3 ). In contrast, two groups of $P$. cryptogea isolates collected from dusty miller at the same location in 2001 (group 1) and 2002 (group 2) showed differences in mefenoxam sensitivity (Table 3). Isolates of $P$. cryptogea collected in 2001 (group 1) had $\mathrm{EC}_{50}$ value of $407.4 \mu \mathrm{g}$ a.i./ml, whereas the isolates collected in 2002 (group 2) had $\mathrm{EC}_{50}$ values of 0.1 or $27.5 \mu \mathrm{g}$ a.i./ml (group 2-a or 2-b, respectively). Both groups of isolates were A1 compatibility type.

\section{DISCUSSION}

$P$. cryptogea, $P$. nicotianae, and $P$. palmivora were isolated from eight floriculture crops grown at seven production

Table 3. Compatibility type and sensitivity to mefenoxam of Phytophthora isolates collected from floriculture crops in North Carolina

\begin{tabular}{|c|c|c|c|c|c|c|c|c|c|}
\hline \multirow[b]{2}{*}{ Group $^{b}$} & \multirow[b]{2}{*}{ Location $^{c}$} & \multirow[b]{2}{*}{ Year isolated } & \multirow[b]{2}{*}{ Host } & \multirow[b]{2}{*}{ Species } & \multirow[b]{2}{*}{ No. of isolates } & \multirow[b]{2}{*}{ Compatibility type } & \multicolumn{2}{|c|}{ Mefenoxam sensitivity $^{a}$} & \multirow[b]{2}{*}{$\mathrm{EC}_{50}{ }^{\mathrm{d}}$} \\
\hline & & & & & & & $1 \mu \mathrm{g}$ a.i. $/ \mathrm{ml}$ & $100 \mu \mathrm{g}$ a.i. $/ \mathrm{ml}$ & \\
\hline 1 & A & 2001 & Dusty miller & P. cryptogea & 52 & A1 & Insensitive & Insensitive & 407.4 \\
\hline $2-\mathrm{a}$ & A & 2002 & Dusty miller & P. cryptogea & 5 & A1 & Intermediate & Sensitive & 0.1 \\
\hline $2-b$ & $\mathrm{~A}$ & 2002 & Dusty miller & P. cryptogea & 44 & A1 & Insensitive & Intermediate & 27.5 \\
\hline $3-\mathrm{a}$ & $\mathrm{A}$ & 2002 & Gerbera daisy & P. cryptogea & 13 & A1 & Insensitive & Intermediate & 5.4 \\
\hline $3-b$ & $\mathrm{~A}$ & 2002 & Gerbera daisy & P. cryptogea & 17 & A1 & Insensitive & Insensitive & 549.5 \\
\hline 4 & B & 2002 & Gerbera daisy & P. cryptogea & 53 & A1 & Insensitive & Insensitive & 416.9 \\
\hline 5 & $\mathrm{C}$ & 2001 & African violet & P. nicotianae & 77 & $\mathrm{~A} 2$ & Sensitive & Sensitive & NA \\
\hline 6 & $\mathrm{C}$ & 2002 & African violet & P. nicotianae & 19 & $\mathrm{~A} 2$ & Sensitive & Sensitive & NA \\
\hline 7 & A & 2001 & Lavender & P. nicotianae & 60 & $\mathrm{~A} 2$ & Sensitive & Sensitive & NA \\
\hline 8 & $\mathrm{D}$ & 2002 & Pansy & P. nicotianae & 8 & A1 & Sensitive & Sensitive & NA \\
\hline 9 & $\mathrm{E}$ & 2002 & Petunia & P. nicotianae & 40 & A2 & Insensitive & Insensitive & 269.2 \\
\hline 10 & $\mathrm{~F}$ & 2001 & Vinca & P. nicotianae & 16 & $\mathrm{~A} 2$ & Insensitive & Insensitive & 346.7 \\
\hline 11 & $\mathrm{D}$ & 2001 & Vinca & P. nicotianae & 9 & $\mathrm{~A} 2$ & Sensitive & Sensitive & NA \\
\hline 12 & A & 2002 & Vinca & P. nicotianae & 44 & $\mathrm{~A} 2$ & Sensitive & Sensitive & NA \\
\hline 13 & $\mathrm{C}$ & 2001 & English ivy & P. palmivora & 17 & A1 & Sensitive & Sensitive & NA \\
\hline 14 & G & 2002 & English ivy & P. palmivora & 9 & A1 & Sensitive & Sensitive & NA \\
\hline
\end{tabular}

a Isolates were (i) sensitive if hyphal growth was little or none, (ii) intermediate if hyphal growth was less than $50 \%$ compared with the growth on control plate, or (iii) insensitive if hyphal growth was greater than $50 \%$ of growth of that on control plate.

b Group defined as isolates of Phytophthora collected from one plant species grown at a given location at a given time of survey. Groups 2 and 3 were subdivided based on the differences in sensitivity to mefenoxam among isolates within each group.

c Phytophthora isolates were recovered from seven production locations. Locations with the same letter represent a single production location.

${ }^{\mathrm{d}}$ Concentration of fungicide giving $50 \%$ growth inhibition $\left(\mathrm{EC}_{50}\right)$ for isolates that grew at $1 \mu \mathrm{g}$ a.i./ml concentration of mefenoxam. $\mathrm{NA}=$ not applicable. 
locations in North Carolina. Occurrence of these three species of Phytophthora on each corresponding host has been reported previously in other parts of the United States. In this study, P. cryptogea was isolated from dusty miller and gerbera daisy. Since the first report of crown and root rot on gerbera daisy in New Jersey, occurrence of this disease caused by $P$. cryptogea has been reported in other areas of the United States $(1,17)$. P. nicotianae was the most prevalent species found in the survey, with isolations from African violet, lavender, pansy, petunia, and vinca. This pathogen is known to have a wide host range of more than 58 different plant families, including various floriculture crops (5), throughout the United States $(1,9,10,14,18,19)$. Ploetz and Engelhard (18) described P. nicotianae (=parasitica) as a causal agent of crown and root rot of African violet. P. nicotianae also is known to cause root rot on lavender (19). Isolates of $P$. palmivora were found from English ivy grown in greenhouses in this survey. Although distribution of $P$. palmivora typically is limited to semitropical and tropical areas, $P$. palmivora caused an outbreak of stem and root rot on English ivy grown in greenhouses in California (13). The pathogen also was isolated from the same host in landscape and nursery settings in South Carolina (6). Species of Phytophthora were isolated from eight of 41 plant species collected. Pythium, Rhizoctonia, and Thielaviopsis spp. were isolated from many plant samples from which Phytophthora spp. were not recovered (data not shown). These fungi have host ranges that overlap with Phytophthora and they can cause symptoms that are similar to symptoms induced by Phytophthora spp. on floriculture crops; therefore, it is unlikely that a surveyor can selectively collect plants infected only with Phytophthora spp.

One half of the isolates (243 of 483) of P. cryptogea, P. nicotianae, and P. palmivora collected in this study were sensitive to mefenoxam at $1 \mu \mathrm{g}$ a.i./ml. A high level of resistance to mefenoxam was observed for isolates of P. cryptogea and P. nicotianae. Three groups of isolates of $P$. cryptogea from dusty miller and gerbera daisy (groups 1, 3-a, and 4) had $\mathrm{EC}_{50}$ values greater than $100 \mu \mathrm{g}$ a.i./ml; hence, disease control by use of mefenoxam alone may be impractical. The $\mathrm{EC}_{50}$ values for two groups of isolates of $P$. nicotianae from pansy and vinca (groups 8 and 10) also were greater than $100 \mu \mathrm{g}$ a.i./ml. All of the production locations where the isolates highly resistant to mefenoxam were recovered had epidemics of Phytophthora blight and crown and root rot in spite of regular use of mefenoxam. Insensitivity of Phytophthora spp. to mefenoxam and metalaxyl has been reported for several floriculture crops $(8,15)$. An isolate of $P$. nicotianae (=parasitica) from Catharanthus roseus in California had an $\mathrm{EC}_{50}$ value of $717.4 \mu \mathrm{g}$ a.i./ml, which was 19 times greater than the highest rate of metalaxyl use labeled for C. roseus (9).

The individual species of Phytophthora recovered were all heterothallic. At a given location, isolates were all the same compatibility type. The inability to form oospores during an epidemic can be a disadvantage to Phytophthora spp. Sexual reproduction enhances genetic variation and promotes survival $(15,21)$. However, oospore survival may not be important for maintaining epidemics because year-round production of floriculture crops under controlled environmental conditions is favorable for asexual reproduction and dispersal inside greenhouses. For 12 of 14 groups, all isolates within a group had the same level of sensitivity to mefenoxam and were the same compatibility type. Similar results were reported for $P$. drechsleri and $P$. nicotianae isolates from several floriculture crops (14). All isolates of $P$. drechsleri and $P$. nicotianae recovered from each location had the same sensitivity to mefenoxam, compatibility type, and AFLP profile. In our study, asexual reproduction of three Phytophthora spp. may play a major role in epidemics within each production location because lack of phenotypic diversity and sexual reproduction by oospore formation were observed. Two groups of isolates (groups 2 and 3) showed a different level of mefenoxam sensitivity even though they were from the same host grown at a particular location. The isolates within each group were the same compatibility type; thus, segregation of mefenoxam sensitivity through sexual recom- bination was impossible. Genetic analysis of these groups is needed to confirm that isolates with different mefenoxam sensitivity within two groups originated from different sources.

Over the 2-year survey, we were able, in some instances, to collect the same Phytophthora spp. from the same host grown at the same location. Isolates of P. nicotianae collected from African violet at one location in 2001 and 2002 (groups 5 and 6) had the same compatibility type and sensitivity to mefenoxam. It is probable that the same isolates survived the period between crops without forming oospores to cause epidemics again the following year Lamour et al. (14) also reported that phenotypic and genetic characteristics were identical for isolates of $P$. nicotianae collected from snapdragons over 2 years. However, isolates of P. cryptogea we collected from dusty miller at one location in 2001 and 2002 (groups 1 and 2) showed a difference in mefenoxam sensitivity. The $\mathrm{EC}_{50}$ value for the isolate group from 2001 was $407.4 \mu \mathrm{g}$ a.i. $/ \mathrm{ml}$, whereas the values for the isolate groups from 2002 were 0.1 and $27.5 \mu \mathrm{g}$ a.i./ml. It is unlikely that a shift toward mefenoxam sensitivity of the isolates was in progress over 2 years. The selection pressure for mefenoxam resistance was similar because fungicide usage was based on the same application schedule for both years. It is possible that the isolates more sensitive to mefenoxam were introduced to the production location during that period and became predominant. In a study of comparison of fitness ability of metalaxyl-resistant and -sensitive iso-

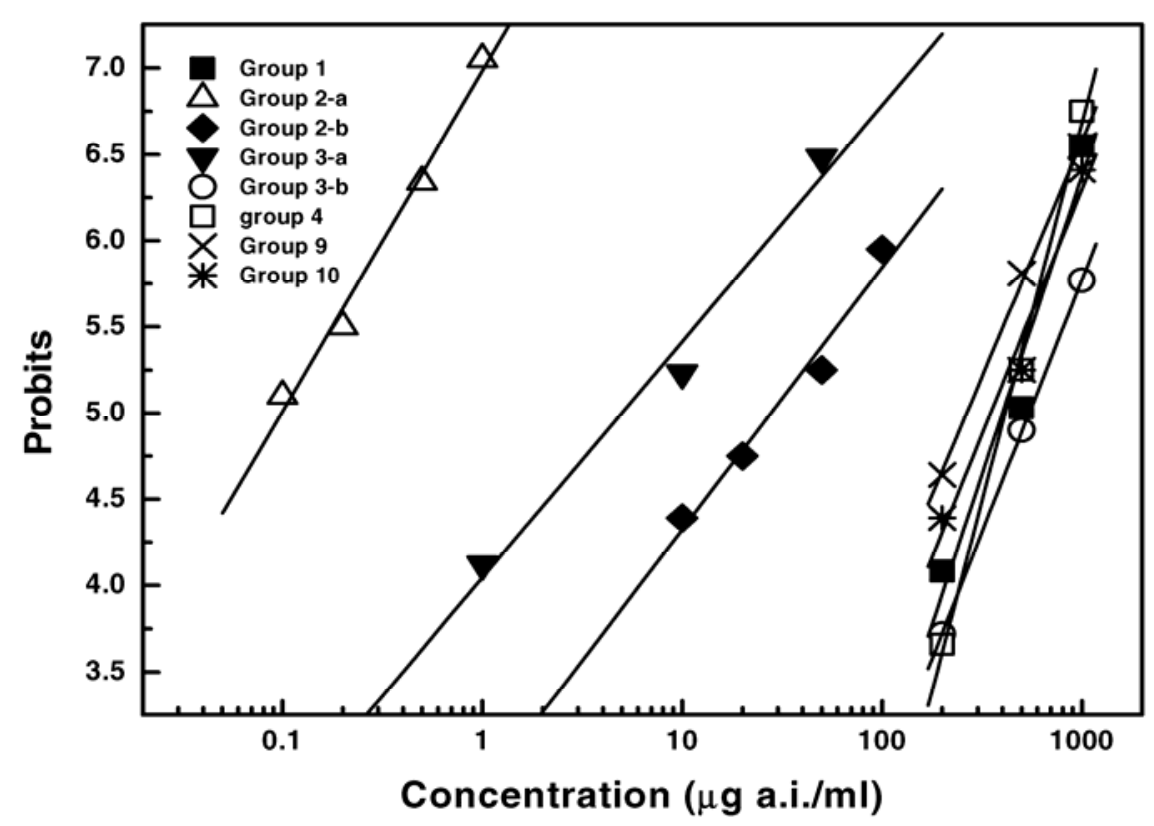

Fig. 3. Dosage-response curve for hyphal growth inhibition of Phytophthora cryptogea and P. nicotianae with mefenoxam collected from floriculture crops grown in North Carolina in 2001 and 2002. Groups 1, 2-a, and 2-b were isolates of P. cryptogea collected from dusty miller. Groups 3-a, 3-b, and 4 were $P$. cryptogea isolates recovered from gerbera daisy. Isolates of $P$. nicotianae collected from petunia and vinca were group 9 and 10, respectively. Percent inhibition of growth by mefenoxam amendment was transformed to probability unit based on a probit table. 
lates of $P$. nicotianae on orange seedlings (28), resistant isolates were less competitive than sensitive isolates in some pairings. However, some resistant isolates were able to compete with sensitive isolates. For other Phytophthora spp., metalaxyl-resistant isolates were more fit than sensitive isolates in some studies, whereas others showed that there was no relationship between fitness and metalaxyl resistance $(4,16)$. Future testing of competitiveness of our sensitive and insensitive isolates of $P$. cryptogea may help answer these questions.

Although in vitro insensitivity to mefenoxam may not always result in fungicide failure in control of Phytophthora diseases on floriculture crops grown in greenhouses, production locations with isolates highly resistant to mefenoxam should use mefenoxam only as a rotational product. It is believed that intensive use of a single fungicide that has a single mode of action can cause rapid development of fungicide resistance $(25,26)$. Rotation of fungicides with different modes of action can reduce selection pressure for fungicide resistance.

Monitoring and characterization of the pathogen population, including fungicide resistance and sexual recombination, may play a significant role in developing an effective disease management strategy. Symptoms and lesions caused by all three species were not limited to root and crown tissues of the plants. Most plants infected by these species showed aboveground symptoms such as leaf blight and petiole rot as well as root rot and crown rot. Intensive production conditions for floriculture crops grown in greenhouses, including dense leaf canopy, tight plant spacing, and overhead irrigation, may increase aboveground dispersal of Phytophthora propagules within a production facility. Sanitation within a production facility and improving the quality of recirculating irrigation water should be included as an integrated approach to prevent introduction of the pathogen and to reduce the inoculum level of the pathogen once it is introduced $(30,31)$. Growers will continue to be challenged in their attempts to manage Phytophthora diseases in floriculture crops due to the diversity of Phytophthora spp., development of fungicide resistance, and movement of plant stocks within the industry.
ACKNOWLEDGMENTS

We thank L. E. Gomez-Alpizar and K. C. Parker for technical assistance; M. L. Daughtrey, S. H. $\mathrm{Kim}$, and $\mathrm{K}$. H. Lamour for providing reference and tester isolates; J. B. Ristaino and C. Y. Warfield for critically reviewing the manuscript; and the North Carolina commercial flower growers who participated in this survey.

\section{LITERATURE CITED}

1. Alfieri, S. A., Jr., Langdon, K. R., Wehlburg, C., and Kimbrough, J. W. 1984. Index of Plant Diseases in Florida. Fla. Dep. Agric. Consumer Serv. Div. Plant Ind. Bull. No. 11

2. Benson, D. M. 1979. Efficacy and in vitro activity of two systemic acylalanines and ethazole for control of Phytophthora cinnamomi root rot of azalea. Phytopathology 69:174-178.

3. Chee, K. H., Zentmyer, G. A., Foong, K. M., and Klure, L. J. 1976. Mating types of Phytophthora palmivora in Malaysia. Plant Dis. Rep. 60:866-867.

4. Cohen, Y., and Reuveni, M. 1983. Occurrence of metalaxyl-resistant isolates of Phytophthora infestans in potato fields in Israel. Phytopathology 73:925-927.

5. Daughtrey, M. L., Wick, R. L., and Peterson, J. L. 1995. Compendium of Flowering Potted Plant Diseases. The American Phytopathological Society, St. Paul, MN.

6. Eisenmann, J. A., Schnabel, G., and Jeffers, S. N. 2003. Characterization of two papillate species of Phytophthora from ornamental plants. (Abstr.) Phytopathology 93:S23.

7. Erwin, D. C., and Ribeiro, O. K. 1996. Phytophthora Diseases Worldwide. The American Phytopathological Society, St. Paul, MN.

8. Ferrin, D. M., and Kabashima, J. N. 1991. Invitro insensitivity to metalaxyl of isolates of Phytophthora citricola and P. parasitica from ornamental hosts in southern California. Plant Dis. 75:1041-1044.

9. Ferrin, D. M., and Rohde, R. G. 1992. In-vivo expression of resistance to metalaxyl by a nursery isolate of Phytophthora parasitica from $\mathrm{Ca}$ tharanthus roseus. Plant Dis. 76:82-84.

10. Grand, L. F. 1985. North Carolina Plant Disease Index. N. C. Agric. Res. Serv. Tech. Bull. 240:1-157.

11. Innis, M. A., Gelfand, D. H., Sninsky, J. J., and White, T. J. 1990. PCR Protocols: A Guide to Methods and Applications. Academic Press, Inc., New York.

12. Kanwischer, M. E., and Mitchell, D. J. 1978. The influence of a fungicide on the epidemiology of black shank of tobacco. Phytopathology 68:1760-1765.

13. Keim, R., Zentmyer, G. A., and Klure, L. J. 1976. Phytophthora palmivora on ivy in California and its control with pyroxychlor. Plant Dis. Rep. 60:632-633.

14. Lamour, K. H., Daughtrey, M. L., Benson, D. M., Hwang, J., and Hausbeck, M. K. 2003. Etiology of Phytophthora drechsleri and P. nicotianae $(=P$. parasitica) diseases affecting floriculture crops. Plant Dis. 87:854-858.

15. Lamour, K. H., and Hausbeck, M. K. 2000. Mefenoxam insensitivity and the sexual stage of Phytophthora capsici in Michigan cucurbit fields. Phytopathology 90:396-400.

16. Lee, T. Y., Mizubuti, E., and Fry, W. E. 1999. Genetics of metalaxyl resistance in Phytophthora infestans. Fungal Genet. Biol. 26:118-130.

17. Pirone, P. P. 1939. Disease of ornamental plants. New Jersey Agric. Coll. Exp. Stn. Circ. 385:1-80.

18. Ploetz, R. C., and Engelhard, A. W. 1980. Crown and root rot of gloxinia and other gesneriads caused by Phytophthora parasitica. Plant Dis. 64:487-490.

19. Putnam, M. 1991. Root rot of lavender caused by Phytophthora nicotianae. Plant Pathol. 40:480-482.

20. Rhoads, D. D., and Roufa, D. J. 1989. SEQAID II. Kansas State University, Manhattan.

21. Ristaino, J. B., and Johnston, S. B. 1999. Ecologically based approaches to management of Phytophthora blight on bell pepper. Plant Dis. 83:1080-1089.

22. Ristaino, J. B., Madritch, M., Trout, C. L., and Parra, G. 1998. PCR amplification of ribosomal DNA for species identification in the plant pathogen genus Phytophthora. Appl. Environ. Microbiol. 64:948-954.

23. Schwinn, F., and Staub, T. 1987. Phenylamides and other fungicides against oomycetes. Pages 259-274 in: Modern Selective Fungicides, Properties, Applications, Mechanisms of Action. H. Lyr, ed. Longman Scientific and Technical, London.

24. Stamps, D. J., Waterhouse, G. M., Newhook, F. J., and Hall, G. S. 1990. Revised tabular key to the species of Phytophthora. Commonw. Agric. Bur. Int. Mycol. Inst. Mycol. Pap. 162.

25. Staup, T. 1991. Practical experience with antiresistance strategies and the role of integrated use. Annu. Rev. Phytopathol. 29:421442.

26. Staup, T., and Sozzi, D. 1984. Fungicide resistance: a continuing challenge. Plant Dis. 68:1026-1031.

27. Thinggaard, K., and Anderson, H. 1995. Influence of watering frequency and electrical conductivity of the nutrient solution on Phytophthora root rot in pot plants of Gerbera. Plant Dis. 79:259-263.

28. Timmer, L. W., Graham, J. H., and Zitko, S. E. 1998. Metalaxyl-resistant isolates of Phytophthora nicotianae: Occurrence, sensitivity, and competitive parasitic ability on citrus. Plant Dis. 82:254-261.

29. U. S. Dep. of Agric. 2003. Floriculture crops: 2002 summary. Natl. Agric. Stat. Serv. Sp Cr 6-1 (03). Washington, DC

30. Van der Gaag, J. D., Kerssies, A., and Lanser, C. 2001. Spread of Phytophthora root and crown rot in Saintpaulia, Gerbera and Spathiphyllum pot plants in ebb-and-flow-systems. Eur. J. Plant Pathol. 107:535-542.

31. von Broembsen, S. L., and Deacon, J. W. 1997. Calcium interference with zoospore biology and infectivity of Phytophthora parasitica in nutrient irrigation solutions. Phytopathology $87: 522-528$. 